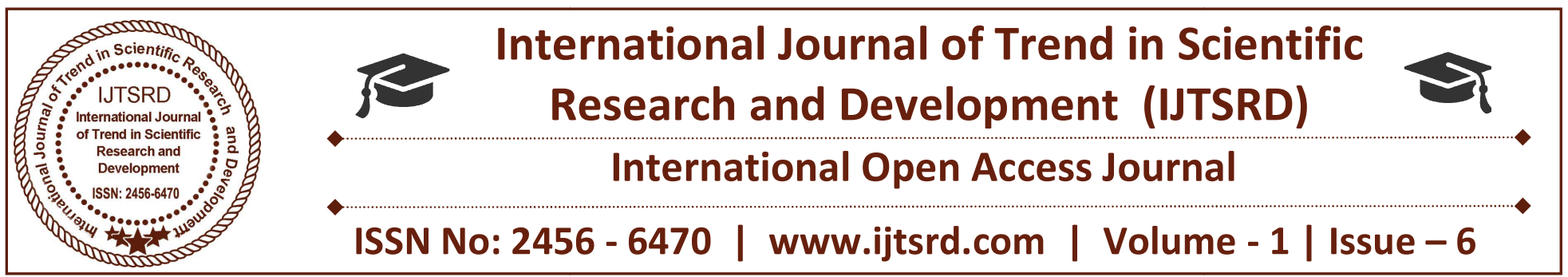

\title{
Effect of Micro, Small and Medium Enterprises (MSMEs) in Sustainable Rural Development in Nigeria
}

\author{
Dr. Felicia OmelogoUchehara
}

\begin{abstract}
The study investigated whether Micro, Small and Medium Enterprises could accelerate sustainable rural development in Nigeria. Through conceptual, theoretical and empirical reviews of existing literature and statistical analyses, the results provide empirical evidence on the relationship of MSMEs and rural development. The study adopted a sample of 336 small business owners that operate in the rural areas of Ihiala, Ogbaru and old Aguata LGAs of Anambra State of Nigeria. The study tested two hypotheses at 0.05 level of significance. A percentage frequency and OLS regression technique were employed for data analyses. The results showed that government involvement has no significant effect on MSMEs development in Anambra State of Nigeria, Furthermore, development of MSMEs has29\% significant effect on rural development in Anambra State. The study therefore infers that development of MSMEs is capable of opening up rural areas in a developing economy like Nigeria. Increased business start-ups, use of indigenous technologies, business and customer growths are small business enhancing features that can be improved to achieve sustainable rural development in Nigeria.
\end{abstract}

Keywords: MSMEs, government involvement, rural development sustainability, Nigeria

\section{INTRODUCTION}

\section{Background to the Study}

The economic transformation of most African countries was due to the interactional trade during the nineteenth century. The increased flow of market relations that followed, created economic revolution in the continent, which transited from pre-capitalist mode of production to a quasicapitalist system. Abinitio, the aim was not for social and political emancipation. Most of the global socio-economic woes confronting the world could be attributed to unequal distribution of political and economic power. The welfare of the economy, environment and people are inextricably link and should be adequately considered in order to avoid imbalance, marginalization and damages prevalent in societies.

Austrian school of economic thought holds the view that free-market economy encourages individuals to act independently and entrepreneurially and expect returns on owner's equity. Pro-market economy writers argued that entrepreneurs and managers, and not government develop businesses. The Thatcher Administration mandate (Thatcherism) frowned at the large firm dominance and corporatism but embraced new public administration or public management which emphasizes $a$ combination of free markets, monetarism, entrepreneurship and individualism (Laxmikanth, 2006; Hutto, 1996).

Presently, the world economy is in a bad shape as a result of steep drop of oil price. Uncertainties in the global economic environment have made pushed economies that hitherto achieved growth to experience drop in growth.

Nigeria, a federal democratic secular republic in West Africa sub-region is one huge market with a population of about 184 million people and has over 500 ethnic groups. As at 2015 global rating, Nigeria is the world's 20 largest country and considered an emerging market, (The CIA World fact book, 2014; 
World Bank, 2012). The protracted military rule in Nigeria, corruption, government unproductive projects and maladministration hindered economic growth. With the enthronement of democratic governance, each of the three tiers of government has initiated various economic policies and strategies for economic empowerment, employment generation and poverty reduction in order to cushion the effects of the perennial socio-economic challenges in the economy. Some of these programmes were import substitution, Structural Adjustment Programme (SAP), micro-finance administration and other medium-term strategies such as development and growth of entrepreneurship and micro, small and medium enterprises. Small businesses have generally gained recognition as economic growth engine, creates jobs, promotes indigenous technology, makes for utilization of raw materials and industrialization. SMEs are most valued as they render specialized service to large firms and provide variety of products to consumer SMEs encourage budding spin-off entrepreneurs to unleash their potentials. Small enterprises are successful sector in the economy and could be more successful if government becomes more proactive in planning, implementing and control of its policies in that sector (www.indexmundi.com, Nigeria).

Nigeria economy is an integral part of the global economy and is not immuned to the socio-economic crises. The economy is a mono-economy and government largely depends on oil revenue. The Nigerian economy is adversely affected by the prevailing lower price and weak demand for oil. Many challenges confront the development of SMEs that account for high rate of failure in the sector. Small enterprises lack the capability to provide sustainable employment that allows for the employed to satisfy basic needs from earned salary, and generate revenue for small business owners. Other problems of SMEs in the economy include unstable economy, bureaucracy, infrastructure decay, lack of access to cheap credit, social insecurity, neglect of the private sector and rural areas (Uchehara 2012, Kent Christopher \& ThiThanh 2006).

According to (Decker 2005, Afolayan, 1995) genuine democracy is noticeable in the life of the citizens, urban and rural dwellers inclusive. The importance of rural communities is that the inhabitants engaged in primary economic activities that form the springboard of economic development. Ezeah (2005) observed that rural dwellers suffer abject poverty and they are mostly, the elderly children and other vulnerable groups. There is absence of basic infrastructure, education institutions, health facilities and private and public sector organizations.

It has been alleged that government has over the years handled the issue of rural development with levity. Previous rural development programmes were merely pet-projects by the wives of the different heads of State. Such projects were for partisan politics, used for campaign manifestos and subsequently abandoned. In addition, such projects lacked legislation and were not based on government policy. Available related literature revealed that existing government rural development programmes were in the provision of farm inputs / agriculture and no attention has been made in accelerating rural development through SMEs. The available existing literature on SMBs and rural development were researches conducted in Europe and America.

\section{Problem of the Statement}

Many well-meaning Nigerians and some international organizations have shown concern on the deplorable conditions of rural areas, infrastructure deficit, high rate of unemployment and abject poverty (Osinbajo. 2015), Ezekwesili,213, www.goggle.com/http/ngr'). The grass root sector / rural areas are of great importance for economic development as Korea and Taiwan had leverage economic development of their rural communities through MSMEs. Research studies in this urea for Nigeria is scarce. The problem of the study therefore is to investigate how MSMEs could be used to enhance sustainable rural development in Nigeria.

\section{Objectives of the study}

The broad aim of the study would critically analyze how SMEs could be used to enhance sustainable rural development in Nigeria. The specific objectives include;

1. To assess government involvement towards the development of MSMEs for sustainable development in Nigeria.

2. To investigate relationship between MSMH's and sustainable rural development in Nigeria. 


\section{Research Questions}

1. To what extent does government involvement influence the development of MSME' in Nigeria?

2. What is the relationship between MSME's and sustainable ruraldevelopment in Nigeria.

\section{Hypotheses}

Ho1: Government involvement does influencedevelopment of MSME's in Nigeria.

Ho2: There is no significant relationship between MSME's and sustainable rural development in Nigeria.

\section{Scope of the study}

The data used for this study was primary data which covered the macro-economic variables from 1999-2015. Variables such as:

$>$ Government involvement and development of SME's, (Finance, knowledge empowerment, capacity building, location of business)

$>$ Government efforts (programmes) and extent of execution (Needs/Seeds/Leeds, NAPEP, Microfinance, FEAP, NDE, YOU WIN).

$>$ SMEs and sustainable development.

\subsection{REVIEW OF RELATED LITERATURE}

\section{Conceptual Framework}

There is no consensus among authors on definition of small business as economic variables vary from country to country and also difference in trend exist over time. The term small business has been variously defined, (Carter and Jones. Evans (2006). Bolton (971) suggested a qualitative or economic approach in the definition of SME. While Cosh and Hugles (2000) offered a definition base on limited product portfolio of small business. The Central Bank of Nigeria categorized small enterprises bused on capital base among other criteria but the World Bank for the purpose of disbursing financial aids used fixed asset yardstick. Generally, authors were of the view that instead of definitions the observable characteristics should be used to identify what constitutes $a$ small business such as; independent ownership, simple management structure, low sales turnover, weak financial base and limited territorial coverage. The National micro policy 2005 categorized businesses in the country into micro, small, medium and large categories.

Small and medium enterprises account for the vast majority of business in Nigeria. This large increase is attributed to a variety of explanations that interface, such as increase in service industry, rapid technological advancement, innovation, cost structure and government policies. SMEs are distinguished from larger forms by the nature of uncertainty small enterprise-face in the mark result of limited product line, added to the fact that they grapple with higher fixed.

Management cost. Micro small and medium enterprises are send to be capable of boosting production, create jobs, reduce poverty and ensure inclusion economic growth and development in Nigeria If proper funded (Solman, 1998:289 and Emefiele, 2016).

Some authors disagreed and argued that large businesses are well positioned to limit uncertainties, participate actively in the economy and earn large amount in foreign exchange. Challenges of SMEs in developing country are numerous unstable economy, high cost of doing business, corruption, infrastructure deficit lack of sustainably and lack of access to cheap credit. There is need for inter-generational equity in business which demands that sustainability is achieved when the efforts of the present docs not jeopardise the opportunity of future generations to satisfy their own needs. It also has to do with continuity and safe guarding the eco-system.

This is in line with Green movement approach that favours the development of small enterprises as against large corporations whose activities are said to have caused deforestation, .depletion of the ozone layer and emitting poisonous gasses into the atmosphere. There are endless lists of peculiar challenges facing SMES in Nigeria such as unfriendly business environment, epileptic power supply, lack of economics, limited knowledge on performance targets, lack of management skills, fake products syndrome among others (Uchehara, 2012, Ranisden\&Beneth. 2005).

According to Liah, Abba, Ishaya and Gana (2013), rural development is a multi-sectorial of initiating strategies towards improving the quality of life and economic well-being of the citizen in sparsely 
populated and isolated areas in a country. Rural areas refer to geographical locations that lie outside densely populated environment of towns and cities whose main occupation is based on primary economic activities. : The World Bank (1990/2000) viewed rural population as people living in rural areas as defined listical offices and between total population and urban population.

The federal office of statistics classified a community as rural if it has a population of less than 20.000 inhabitants. Rural areas are usually characterized by lack of road networks, health facilities, educational institutions, communication, and the dwellers live in perpetual poverty (IMF, 2014).

Rural sector in Nigeria is of great importance to the socio-economic development if given the proper attention by the government, public administration and the organised private sector.

The term 'new public management' was first used by Christopher Hood to signify a public management for all seasons. It is also referred to as managerialism, entrepreneurial government or market-based public administration. The concept is relatively new and evolved from Thatcherism 1979. Britain initiated the concept / privatization of public enterprise Reaganisin (USA) followed in the 1980's. It lays emphasis on 3Es economy, efficiency and effectiveness (Laxmukanth, 2006. Nyagba. 2009). According to the writers the set goal of the new public management is centred on change, technology, debureaucratization, entrepreneurship responsiveness and performance targets among others.

In addition, the tiers of government should change from a 'doer of public benefits to a facilitator, promoter and provider of change and good governance. As the global society embraces globalization liberalization, privatization and deregulation government need to reorganize and extend democracy dividend to both urban and rural dwellers (Yunusa, Okene\&Badamasi, 2008). Commenting further, the authors opined that development policy is that practice and process of government bringing quality life to the citizens in the rural communities. Rural areas are endowed with abundance of both natural and human resources. For (World Bank. 1985), development includes democracy, free market economy, human rights, gender equality, population and environmental control. It is about the citizens and for them to achieve skills, acquire knowledge and live above poverty line. Governance is the act of collectively solving societal problems and government is the instrument that seeks change itself for the good of the society. According to Todaro (2003: 418) sustainable development is achievable if it has its lap root at the rural areas. The unending social problem such as inequality, unemployment, poverty and retarded economic development of the citizens are as a result of lack of development of the rural areas. Over the decades, rural development has been neglected by previous governments in Nigeria through lack of policies, lack of continuity of leading projects of previous administrations. Writers were of the view mat urban centres are saturated with facilities. Challenges facing rural dwellers in Nigeria include absence of basic infrastructure, lack of portable water, modern markets, health facilities and educational institutions.

\section{GOVERNMENT INVOLVEMENT IN THE DEVELOPMENT OF MSMES FOR SUSTAINABLE RURAL DEVELOPMENT: 1999- 2015}

In this sub-unit government involvement was discussed under: government strategies for the development of SMEs and government efforts in sustainable rural development in Nigeria. The various government support initiatives for the development of small enterprises $n$ Nigeria were especially response to the endemic socio-economic problems to encourage people to become active economic partners in the economy cushion the effects of inflation and for poverty reduction. The role of governmentaction for the MSMEs has been justified by three different arguments.

$>$ The market failures are real also do have negative effect on Micro. Small and Medium Scale Enterprise (MSMEs) which by their nature are small in all ramifications.

$>$ The small enterprises are flexible, innovative, and easy to modify and have capacity to create jobs.

$>$ Government has the capacity to act as strategic vision union planner and promoted for the overall economy which small businesses cannot do. Government attitude towards the development of SMEs viewed from these areas:

i. Finance : grant, subsidies, micro finance

ii. Knowledge: Empowerment through access to information and location trends. 
iii. Support with specialist advice and counseling on business creation.

iv. Capacity building: through trading and human development (Graham 2004)

Available related literature suggested that government action could be in form of policy methods which are expressed on finance, empowerment, providing expert advice and human development initiatives.

Targeting is in the form of start-up procedures, generating business ideas, entrepreneurship and expansion in form of BUSINESS ORGANIZATION like types, sizes, exporters/non exporting businesses. General information on businesses climate-businesses ethics, regulatory averment menaced micro averment of businesses (CBN. 2005)

\section{SOME GOVERNMENTAL STRATEGIES FOR THE DEVELOPMENT OF SMEs from 1999-2013}

\section{Import substitution}

In the 1980s government economic policy was on import substitution. This was the era of Nigeria/Industrial Development Bank Ltd and Industry and Nigerian Bank for commerce and Industry which is referred to as "the golden period" for SMEs in Nigeria. The hanks helped the SMEs source for loan from foreign financiers at very cheap lending rates for a duration of 5-7 years with about 2 years moratorium within which only the Interest was paid. Other motivating incentive for the SMEs then were; acquisition of fixed assets such as land and building through owners' equity, while the banks provided capital. The rate of exchange then was 65 kobo to dollar. As a result of the prevailing favourable business environment, capacity utilization peaked at 73.3 percent, gross domestic product (GOP) increased and poverty level stood at 27.1 percent. Basically import substitution implies that importation could be substituted with local production.

$>$ National Microfinance policy was launched by the federal government with the $\mathrm{CBN}$ as its implementing agency. Part of the component of micro finances and fund to strengthen the link between SMEs and access to cheap credit for MSMEs in the economy. The objective of the fund is to enhance the ability of micro finance institutions to meet 1 he credit needs of small enterprises.
$>$ Intervention Fund. In addition the CBN had over the past 5 years set up special intervention funds with over 1.3 trillion Naira with the SMEs subsector atone getting about 600 billion naira. Also bank of Industry (BOI) created many SMEs targeted funds worth hundreds of billions of naira.

Job creation. Federal Ministry of Finance initiated Young Women Entrepreneurs in Nigeria (YOUWIN) on $3^{\text {rii }}$ September 2012.'The program has as the target the young between the age brackets of 15-35 years but later expended to 14-40 years. The arm was to empower women entrepreneurs which will benefit the family and the larger society and the economy in general. It is believed that most of SMEs operators are women. YOUWIN has nurtured over 2.400 young entrepreneurs with 22,000 jobs created. Government launched N50 million to help YOUWIN beneficiaries and other visible SMEs to achieve high performance and create more jobs.

$>$ G-Win - means the growing girls and women initiatives in Nigeria. This was launched in 213 to integrate women and girls into the sectors of the economy. About 2.285 young women have been trained in ICT, while 2,362 VVF have been treated (Budget 2075) .

Other government medium term plan included:

Fiscal incentives such as tax holiday for the first 6 years of the SMEs operations.

Monetary authority support introduced by CBN which stipulates credit guidelines that compelled commercial and merchant banks to set aside a portion of their loanable fund to SMEs. Other incentives were more in the areas of science and technical initiatives and these were successful in Korea and Taiwan and contributed to their industrialization (IMF 2005, World Bank 2014).

Despite the huge expenditure for the development of SMEs in Nigeria, the subsector does not have a success story. A recent report on SMEs indicated that less than 5 percent of the funds so farreached the SMEs. The failure of SMEs may be systematic, inconsistency in government policies, unstable economy, managerial incompetency, inaccessibility of relevant information, reluctance to share equity and neglect of the private sector and rural areas. In this study, government involvement in the 
development of SMEs for sustainable rural development was measured with the following variables;

$>$ Finance- grants, subsidies, loan

$>$ Information- Accessibility of informationon local and international trends for SMEs development.

$>$ Supportive agencies - counselling and advice

$>$ Capacity building - workshops, seminars and conferences.

$>$ Business location - urban or rural

\section{Government Efforts in Sustainable rural Development in Nigeria}

Bureaucratic structures are necessary but not sufficient structure and responsiveness to economic needs of a nation. There need to be multi-organizational arrangements that would respond to the yearnings of the citizens through provision of good services. Policies and principles are needed and also adoption of private sector management practices based on concepts such as accountability, performance management, collective incentives, rewarding achievement and private sector model of production are also required.

The need to develop the rural sector has drawn the attention of policy-makers and governments as majority of the population lives in rural areas.

The period under renew in this study is 1999 to 2015 was a democratic dispensation characterized by electoral, social/ economic crises in Nigeria. The electoral processes were marked with. Irregularities(Decker 2005). During the period SMEs experienced decline most especially from: the Structural Adjustment Program (SAP), Quantum ofnaira was spent in buying foreign; exchange, unemployment rose to alarming rate, devaluation of naira. Hyperinflation, neglect of Economic growth, Relief came in the telecommunication industry that created micro related businesses. "According to World Bank Report, Nigeria was ranked 169 out of 189 countries sampled on "Ease of doing business. The report also stated the government has the responsibility to create the right and sound environment for economic activities to thrive (vvww.naija.com).

IMF (2014) observed that various countries in the Sub-Saharan African have committed financial and material resources towards elusive rural development.
The effectiveness of the SME support programmes in Nigeria is not clear. Some of the celebrated government efforts for SMEs were more political than economic. Goss (1991) stressed that government support initiative should be sustainable, that development programs must not have negative effects on natural systems that are supportive to life on earth, which includes; the atmosphere, the soil, waters and living beings. In other words, pursuing economic growth should not jeopardize the opportunity of the next generation to satisfy their own basic needs.

- Youwin

- Needs/Seeds/Leeds

- NAPEP

- Micro finance Banks

\section{Theoretical framework}

The section reviewed the free market theory as suitable for this study. Government has initiated agricultural related programmes such as Operation Feed the Nation (OFN), Green Revolution and Back to Land among others. Research studies on SMEs for rural development is scarce. Free market policy aims at preventing monopolistic tendencies, ushers in enterprise culture, collectivism, change, innovation, economic intervention or bail out. The theory uses mechanism and market forces to coordinate and direct economic activity and it encourages profits motive. Other countries have achieved economic development based on freemarket approach, Goss (1991).

\section{Empirical Review}

Ramsden and Benneth(2005) investigated the effect of SMEs on job creation. The study was carried out in US with firms employing less than 2 workers. Descriptive survey design was used. Result was that there is no doubt that SMEs create employment in developed economies.

Poutziouris(2005) conducted a research on the personal/social networks of entrepreneurs and the SME owner manager. Location was Europe and survey method was employed. Findings indicated that entrepreneurs and owner managers of SMEs are motivated more by an interest in understanding the impact of social networks in creating, developing and growing their small firms. 
Adenipekun(2013) carried out a survey research on sustainable rural, infrastructural development in Nigeria within the context of vision $20 ; 2020$. Location was Atakunmosa West Local Government

Area of Osun state, Nigeria, and 12 settlements were sampled. Research .findings revealed that income of the rural dwellers was from subsistence farming, there was obvious lack of basic infrastructures, intolerable living conditions and-high rate of illiteracy.

Several strands of literature exist on the relationship between SMEs and job creation and / or SMEs ownermanager abilities to create, manage and grow small enterprises for economic development in advanced economies. None exist in analysing if SMEs could be used in enhancing development of rural areas in a developing economy like Nigeria.

\section{Summary of Reviewed Literature}

Authors wore of the view that problems of inequality, poverty and other socio-economic problems in societies today were due to government inability to manage resources adequately for the good of the society. The first known recorded shift in public administration in favour of the new public administration or entrepreneurial government was first practiced by Britain through privatization in 1979 and US followed in I980's. Since then most governments have realized that empowering the people makes for enduring development for both urban and rural dwellers. The rural sub-sector in Nigeria is a neglected area as government projects were sited in cities only, hence the drift from rural areas to urban areas. The rural communities are inhabited by old, sick, children and oilier vulnerable groups. The rural sector lacks basic infrastructure, hospitals, schools, portable drinking water and deprived of government and organized private sector establish mentor organizations. Government efforts in developing rural areas had only been in giving agricultural inputs to farmers. Korea and Taiwan that were once referred to as crafts economics have achieved development of their rural countries through SMES. Some authors have argued that large businesses were better in development of economies. Empirical review indicated that SMES were better suited. This study actually evaluated the existing literature on the theme and discovered that SWES are growth engine of development so as to reduce poverty, bridge the inequality, create jobs and thus convert rural areas from being neglected to economic hub. This study is based on free-market theory.

\subsection{METHODOLOGY}

\section{Research Design}

The study adopted descriptive survey research designs. The study is descriptive because it aimed at observing; describing and documenting aspects of a situation as it naturally occurs rather than explaining them (Pilot mid Hurgler, 1995 cited in Apeyusi. 2012). More specifically, descriptive research was adopted because the data collection was for the purpose of describing and interpreting existing relationships, conditions, prevailing practices, beliefs, attitudes, on-going processes, and its central purpose is not just description of what is but the discovery of meaning (Ndagi, 1984). The rationale behind the use of this approach is that it does not usually follow a rigid and tightly woven plan, rather sanctions inquiry into selected issues in great depth, and also allows for flexibility in terms of data collection and analysis.

\section{Population of the study}

The population of the study consists of the Micro, Small and Medium Enterprises (MSMEs) that operate in the rural areas of Anambra State of Nigeria. The database of the Ministry of Commerce and Industry showed that 2082 are registered in Anambra Slate. The local government areas sampled were Ihiala, Ogbaru and old Aguata LGAs.

\section{Sample and Sampling Techniques}

The study adopted a random sampling technique to select 373 managers of MSMEs in Anambra State of Nigeria. Since the target population is large, the sample aims to use the opinion of a sample of managers to generalise on the effect of Micro, Small and Medium Scale Enterprises (MSMEs) for sustainable rural development in Nigeria. It is also important to use an appropriate sample because larger sample size is better as the sample approximates the population unlike in a smaller sample the result in sampling error (Nwabuokei, 2001). Hence, a mathematical model developed by Tare Yemeni (1964) is used to determine the appropriate sample size: $\mathrm{n}=\frac{\mathrm{N}}{1+\mathrm{N}(\mathrm{e})^{2}}$ 
Where $\mathrm{n}=$ Sample size; $\mathrm{N}=$ the population of selected institutions (2082); e = Level of significance

(0.05). In this study the researcher will work on $95 \%$ confidence level.

Applying the above model, we have

$\frac{2082}{1+2082(0,0025)}=\frac{2082}{6.205}=$

$\frac{2082}{1+2082(0.05)^{2}}=$

335.5359 (which is approximately 336)

Anticipating a response rate of $90 \%$, an adjustment of the sample size estimate to cover for non-response rate was made by dividing the sample size calculated with a Factor, f i.e. $\mathrm{n} / \mathrm{f}$, where $\mathrm{f}$ is the estimated response rate. Therefore, the calculated sample size $=336 / 0.90=$ 373.333. Therefore, the sample size for the study is 373 owner-managers of the selected MSMEs in Anambra State of Nigeria.

\section{Instrument for Data Collection}

An item of structured instrument which was developed to relied such option as Not at all (NAA), To a lesser extent (TLE), To some extent (TSE), To a great extent (AGE) and To a very great extent (TVGE) popularly called the modified five(5) point Likert-type scale was used to generate data from the respondents. The choice of the Likert scale was informed by the fact that it presents the respondents with the opportunity of indicating the extent to which they agree or disagree with the statements of the item.

\section{Validation and Reliability of Instrument}

The instrument was face and content validated. Management experts in one of the Nigerian universities assisted to criticize the instrument with the view of ascertaining that it captures the objectives of the study and designed elicit correct responses. However the instrument was pilot testing using a sample of 20 owner managers from Imo State. The reliability of the instrument was determined through a method known as test re-test. The instruments was first given the target respondents and then repeated after an interval of two weeks on the same respondents. The responses on the first and second administration were collated and analyzed for consistency through the application of Spearman Rank Order Correlation Coefficient. The analysis returned coefficients of 0.83 .

\section{Method of Data Collection}

The data for the study will be collected from questionnaire to be distributed to the target sample using direct questionnaire administration technique. The researcher will employ the services of five research assistants to cover questionnaire distribution to owner managed business in rural areas of Anambra State including Ihiala. Ogbaru, Aniocha and Old Aguata Local Government Areas. The process of questionnaire administration will involve giving the respondents the questionnaire and waiting behind to receive it same day or in a later scheduled date. With the help of this method and use of research assistants, $t \mathrm{t}$ is hoped that all the questionnaires will be properly completed and returned to achieve maximum questionnaire distribution response.

\subsection{Model Specification}

Two models are developed to guide objectives one and two respectively. These are the government attitude and development of MSMEs Model and MSMEs and sustainable rural development model.

\section{Government involvement and development of MSMEs Model}

Government involvement can enhance the growth and development of MSMEs in an economy. Government attitude can be measured in terms of Finance, knowledge empowerment, and capacity building towards the growth of MSMEs.

$$
\text { MSMEs }=\mathrm{f}(\text { FIN }, \text { KPOW }, \text { CB })
$$

The equation of the model is thus:

MSMEs- $\mathrm{a}_{0}+\mathrm{a}_{1}$ FIN $+\mathrm{a}_{2}$ KPOW 4- $\mathrm{a}_{3} \mathrm{CB}+$ $\mu i$ (2)

Where: FIN, KPOW and $\mathrm{CB}$ are government Financing of MSMEs, knowledge empowerment, and capacity building as proxies for government involvement towards MSMEs. The coefficients are represented with $a_{0}, a_{1}, a_{2}$. $a_{3}$, which capture the relationships that exist between the dependent and the independent variables, $\mathrm{a}_{0}$ is the constant and $\mathrm{u}$ is the error term. The appriori expectation of the model is that government involvement should have positive 
relationship with sustainable development of MSMEs.

\section{MSMES and Sustainable Rural Development Model}

The functional relationship between developments of MSMEs mid rural development can be represented as below:

$S R D=f(B S, I T, B O, C G)$

The equation of the model is thus:

$\mathrm{SRD}=\mathrm{b}_{0}+\mathrm{b}_{1} \mathrm{BS}+\mathrm{b}_{2} \mathrm{IT}+\mathrm{b}_{3} \mathrm{BG}+4_{3} \mathrm{CG}+\mu i$

Where BS, IT, BG and CG are Increased Business startups, Promotion of indigenous technology, Business growth and Customer growth, respectively, as proxies for sustainable MSMEs development. The coefficients are represented with $b_{0}, b_{1}, b_{2} . b_{3}$, and $b_{4}$, which capture the relationships that exist between the dependent and the independent variables, $\mathrm{a}_{0}$ is the constant and $\mu$ is the error terra. The appriori expectation of the mode] is that sustainable development of MSMEs should have positive relationship with sustainable rural development.

\section{Method of Analyses}

The analysis was designed to be quantitative. Therefore, descriptive statistics and multiple regression analysis would be the major statistical tools used in analyzing the data. However, summary statistics of percentages were used to analyze personal data of the respondents such as sex, educational qualification, and age of the business.

The Ordinary Least Square regression technique was adopted to analyze the relationship between dependent variables and the independent variables in each of the models. Though data from Likert scale responses are ordinal scale which tend not to have normal distribution, however. Norman (2010) cited in Gail and Artiuo (2013) has proven with compelling evidence that parametric tests not only can be used with ordinal data such as Likert scale but also that parametric tests are more robust than non-parametric tests. "This means that parametric tests tend to give the right answer" even when statistical assumptions such as normal distribution of data are violated to an extreme degree: Thus "parametric tests are sufficiently robust to yield largely unbiased answers that are acceptably close to "the truth" when analyzing Likert scale responses".

The OLS regression technique will be employed for the study. The OLS regression was preferred because it has the property of being the Best Linear Unbiased Estimator (BLUE). To ensure the robustness of the results, the analysis was equally subjected to multicolinearity and autocorrelation tests. DurbinWatson (DW) test for autocorrelation was used. This is used to check for the appropriateness of the models for analysis. Any equation with DurbinWatson less than or greater than values not approximately 2, is not acceptable. Unacceptable Durbin-Watson suggests that the analysis cannot be relied on.

Reliability of a model is the measure of the extent of robustness of the results obtained from data analyses. Since the essence of research is to provide evidence that a condition exist, how dependable such evidence could he affects its usefulness in real life application. The robustness of results from multiple regression model is usually affected when multicollinearity exist in the explanatory variables of the model. In the view of Ranjit (2006) the presence of multicollinearity in the data only makes regression estimators imprecisely estimated. When the goal of a regression analysis is to predict $\mathrm{Y}$ from a set of $\mathrm{X}$ variables, the problem of multicollinearity may be arise: the predictions wouldremain accurate and the coefficient of determination (overall $\mathrm{R}^{1}$ or adjusted $\mathrm{R}^{2}$ ) quantifies how well the model predicts the $\mathrm{Y}$ values. However, if the goal is to understand how the various Xs impact Y, multicollinearity becomes a big problem in model estimation. It is therefore necessary toascertain the presence multicollinearity and finds means to correct it.

Since one major goal of the study is to understand how the $\mathrm{X}$ variables impact on $\mathrm{Y}$. the test of multicollinearity must be done to ensure that one independent variable does not excessively influence the behaviour of others in the model. Symptoms of multicollinearity may be observed in situations: (1) small changes in the data produce wide swings in the parameter estimates; (2) coefficients may have very high standard errors and low significance levels even though they are jointly significant and the $R^{2}$ for the regression is quite high; (3) coefficients may have the "wrong" sign or implausible magnitude (Greene, 2000: 256). If these statistics are wrongly given, then 
the result becomes unreliable. Thus is necessary to estimate for multicollinearity to determine how robust the result from OLS would be. The Variance Inflation Factor (VIF) was used for the test of multicollinearity in the model. VTF shows how multicollinearity has increased the instability of the coefficient estimates
(Freund \&LitteIl 2000: 98). The Decision Rule: "if any of the VIFs exceeds 10 (or 5), it is an indication that the associated regression coefficients are poorly estimated because of multicollinearity" (Ranjit. 2006).

\subsection{RESULTS}

Table 1: Descriptive Characteristics of business owner managers in Anambra State of Nigeria

\begin{tabular}{|c|c|c|c|}
\hline Demographic Characteristics & Categories & Frequency & Percentage \\
\hline \multirow[t]{2}{*}{ Gender } & Male & 109 & 32,44 \\
\hline & Female & 227 & 67.56 \\
\hline \multirow{3}{*}{$\begin{array}{c}\text { Years of experience in current } \\
\text { business }\end{array}$} & Below 5 years & 131 & 38.98 \\
\hline & Between 5 to 10 years & 95 & 28.27 \\
\hline & Above 10 years & 110 & 32.73 \\
\hline \multirow[t]{5}{*}{ Educational Status } & Primary Education & 13 & 3.87 \\
\hline & Secondary Education & 147 & 43.75 \\
\hline & NCI: or OND equivalent & 88 & 26.19 \\
\hline & HND or BSc equivalent & 75 & 22.32 \\
\hline & Postgraduate degree & 15 & 3.87 \\
\hline
\end{tabular}

The characteristics of the respondents showed that 109 males representing $32.44 \%$ of the sample and 227 females being $67.56 \%$ are involved in the study. Also, small business owners that has less than five (5) years of business operation ore 131 (38.98\%) as compared to 95 respondents $(28.27 \%)$ with a range of five to ten years of business start-up experience and $110(32.73 \%)$ of them with over ten years of business tart-up experience. Again, $3.87 \%$ of the small business owners that participated in the study have only primary school education as compared to $147(43.75 \%)$ with secondary school education. Moreover, NCE/OND holders accounted for $26.19 \%$ while $\mathrm{HND} / \mathrm{BSc}$ and postgraduate degree holders form $22.32 \%$ and $3.87 \%$ of the sample respectively. The characteristics of the sample indicated that greater number of the small business owners in Anambra State of Nigeria attendance secondary school. Also, the sample showed younger business are abound in Anambra State which suggest that high rate of business startups in a developing economy like Nigeria. 
Table 3: OLS Regression result of the Relationship between rural development and development of MSMEs

\begin{tabular}{|c|c|c|c|c|c|c|}
\hline \multirow[t]{2}{*}{ Model } & \multicolumn{2}{|c|}{$\begin{array}{l}\text { Unsiandardized } \\
\text { Coefficients }\end{array}$} & \multirow{2}{*}{\begin{tabular}{|c|}
$\begin{array}{c}\text { Standardize } \\
\text { d }\end{array}$ \\
Coefficients \\
Beta \\
\end{tabular}} & \multirow[t]{2}{*}{$\mathbf{T}$} & \multirow[t]{2}{*}{ Sig, } & \multirow[t]{2}{*}{ VIF } \\
\hline & $\mathrm{B}$ & Std, Error & & & & \\
\hline (Constant) & 3.226 & .425 & & 7.584 & .000 & \\
\hline $\mathrm{BS}$ & .085 & .120 &, 074 & ,711 & .478 & 1.551 \\
\hline IT & .068 & .118 & .053 & .579 & .564 & 1,211 \\
\hline BG & .360 & .087 & .422 & 4,143 & .000 & 1.498 \\
\hline $\mathrm{CG}$ & .166 & .104 & .190 & 1.598 & .113 & 2.036 \\
\hline \multicolumn{7}{|c|}{ Coefficient of Determination $(\mathrm{R} 2) \sim 0.287$} \\
\hline \multicolumn{7}{|c|}{ F-Sfatistics $=10,388$} \\
\hline \multicolumn{7}{|c|}{ F-Probability $=0,000$} \\
\hline \multicolumn{7}{|c|}{ Durbin Watson $=2.324$} \\
\hline
\end{tabular}

Predictors: (Constant), CG, IT, BG, BS; Dependent Variable: 3RD

The second model of this study aims to examine the effect of Micro, Small and Medium Scale Enterprises (MSMEs) development on rural development in AnambraState of Nigeria. The result above showed that none of the variables have VIF statistics 10 , which indicate that there is no multicollinearity in the model employed in these analyses.

The explanatory power of the model is determined by the coefficient of determination of value 0.287 . The result shows that about $29 \%$ of the rural development factors are captured in the development of MSMEs in Anambra Slate of Nigeria. The F-statistics (10.388) is statistically significant at 0.000 level of significance. The result indicates that development of MSMEs have about: 29\% significant effect on rural development in Anambra State. This implies that as MSME businesses spring up and grow, rural areas can open up. All the variables of MSMEs development employed in the study have positive relationship. However, on Business Growth is found to have statistical significance in the model.

\section{CONCLUSION}

The study has found that development of MSMEs is capable of opening up rural areas in a developing economy like Nigeria. Increased business start-ups, use of indigenous technologies, business and customer growths are small business enhancing features that can be improved to achieve sustainable rural development in Nigeria. However, the efforts Nigerian government so far have rather engendered adverse effect on the growth of these younger entrepreneurial, efforts of small business owners in Nigeria. Capacity building has been a variable factor to sustainable MSMEs development in the area. This implies that self-efforts have been the major influencing factor to business development in Nigeria. Nonetheless, business can thrive even in an unfriendly economy provided that entrepreneurial skills that can engender business start-ups and boost indigenous technologies, business and customer growths. 


\section{RECOMMENDATIONS}

Subsequent government programmes targeted at MSMEs should focus on development entrepreneurial skills.

\section{REFERENCES}

1) Adenipekim, M.T (2013). Sustainable rural infrastructure development in Nigeria within the context of vision 20: 2020; International society for development and sustainability, 2(1), 56- 79.

2) Afolayan, S.O. (1995). Community mobilizationfor rural development in Bangladesh; Lessons for Nigeria Horin. Agricultural and rural management Training Institute (ARMTD)

3) Apeyusi, P. (2012). The impact of Reward systems on corporate performance: A case study of Ghana commercialBank Ltd. A thesis submitted to the Institute of Distance learning, Kutume Nkrumah University of Science and Technology, In partial fulfillment of the requirements for the degree of Commonwealth Executive Master of Business Administration. Retrieved on 21 November 2014 from http://wvspace.knust.edii.gh\%Fjspu\%2Fjspu $\% 2 \mathrm{FP}$ atrick\%2520Apeyusi.pdf.

4) Birch, D. (1979). The job generation process: MIT programme on neighbourhood and regional change. Massachusetts. USA

5) Carter, S. and Jones. Evans. D. (2006) Enterprise and small business. Principles, practice and policy $\left(2^{\text {nd }}\right.$ ed). Tokyo. Prentice hall

6) Cosh. A. and Hughes, A (2000). British enterprisesin transition. Cambridge. CBR

7) Decker. Alexander (2005). Party politics and democratic governance in Nigeria: 1999-2016.

8) Ezeah. P. (2005). Rural sociology and rural development with focus on Nigeria. Enugu: JohnJacob Classic publishers.

9) Ezekwcsili, O. (2013). Nigerian newsdesk 22/05/13. Retrieved $5.02 \mathrm{pm}$ local time.

10) Gail, M.S \&Artino, A.R (2013). Analysing and Inerpreting data from LIkert type scale. Journal of graduate medical education, December University of Connecticut 253 FarmingtonAvemie, CT 060305215. http//d^.doi.org

11) Goss, D. (1991). Small business and society. Erapirieal investigation of thefuture of small businesses.

12) Graham, L. (2004) Graham review of the small business firms loan guarantee. HM Treasury.
Greene, W.H (2000). Econometric analysis (4ed). Upper Saddle river. New Jersey: Prentice Hall.

13) Hulton. W. (1996). The state we're in. London Vintage

14) Kent. E. D. \&Thi Thank (2006). SME exporting challenges in transitional and developing economies. Journal of small business and enterprise development, 13(4).

15) Laah, O.E, Abba, M. Tshaya, D.S and Gana, J.N. (2013). The mirage of rural development in Nigeria. Journal of social sciences mid public policy. 5(2).

16) Laxmikanth. M. (2006). Public administration(third ed.) New Delhi. Tata. McGraw - Hill Publishing Company Ltd.

17) Ndagi, J.O (1984). Essentials of research methodologyfor Nigerian education. Ibadan: University Press Ltd.

18) Nyagba, S. (2009) "Review of Nigeria's rural development policy for sustainable development" Paper presented at business round table at Abuja. II July

19) Poutziouris. P. (2005). Performanceof family firms. Financial times. 28 January.

20) Ramsden, $M$ and Benncth. R.J (2005). The benefit of external supports to SMEs: Satisfaction levels. Journal of smallbusinesses and enterprise development.

21) Ranjit N. (2006). Multicol linearity:Causes, effects and remedies. Retrieved: http://www.res.in/seminar/AS.299/Ebooks\%5c200 $5-2006 \% 5$ dhtsc

22) Solman. G.T (1998) "Value profits of male and female entrepreneurs". International small business journal 6 (3)

23) The CIA World Factboofc(2014). Sky horse publishing. Inc 2013. ISBN 978162636070. The IMF report (2014)

24) The World Bank (2014), World development indicators. Countries and economies. Retrievedfromhttp//data.worldbankorg/coiintry

25) Todaro and Smith (2003). Economic development ( $8^{\text {th }}$ ed) India. Pearson Education. P. 418 Uchehara, F. O (2012) theory and practice of small and medium management. ( $2^{\text {nd }}$ ed.).

26) Onitsha. Feros publishers. Vanguard newspaper online 2016 Ivww.goggle.com / http.ngr

27) Yunusa. M.,Hasim, Okene, A.Z.\& Badamasi.1. (2008) Implementation of rural development policies in Nigeria. Agenda for the liiture. Journal of Research in National development 6(1) 